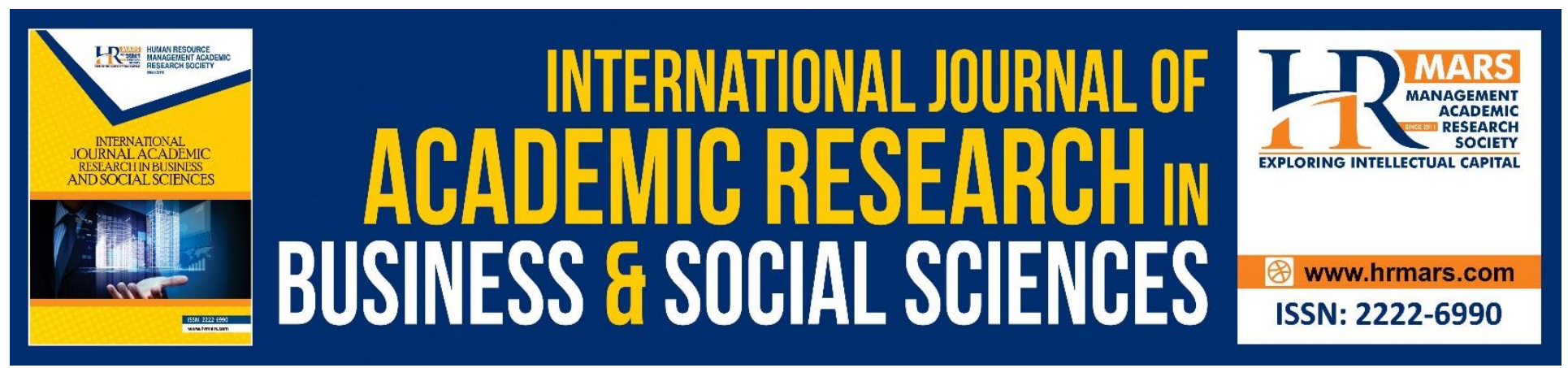

\title{
Effect of Environmental and Political/Legal Risk Management on Performance of Commercial Real Estate Entrepreneurial Investments in Kenya
}

James K Mbugua, Robert Otuya, Stella Muhanji

To Link this Article: http://dx.doi.org/10.6007/IJARBSS/v10-i5/7222

DOI:10.6007/IJARBSS/v10-i5/7222

Received: 02 March 2020, Revised: 25 April 2020, Accepted: 30 April 2020

Published Online: 20 May 2020

In-Text Citation: (Mbugua et al., 2020)

To Cite this Article: Mbugua, J. K., Otuya, R., \& Muhanji, S. (2020). Effect of Environmental and Political/Legal Risk Management on Performance of Commercial Real Estate Entrepreneurial Investments in Kenya. International Journal of Academic Research in Business and Social Sciences, 10(5), 507-521.

\section{Copyright: (C) 2020 The Author(s)}

Published by Human Resource Management Academic Research Society (www.hrmars.com)

This article is published under the Creative Commons Attribution (CC BY 4.0) license. Anyone may reproduce, distribute, translate and create derivative works of this article (for both commercial and non-commercial purposes), subject to full attribution to the original publication and authors. The full terms of this license may be seen

at: http://creativecommons.org/licences/by/4.0/legalcode

\section{Vol. 10, No. 5, 2020, Pg. 507 - 521}

Full Terms \& Conditions of access and use can be found at http://hrmars.com/index.php/pages/detail/publication-ethics 


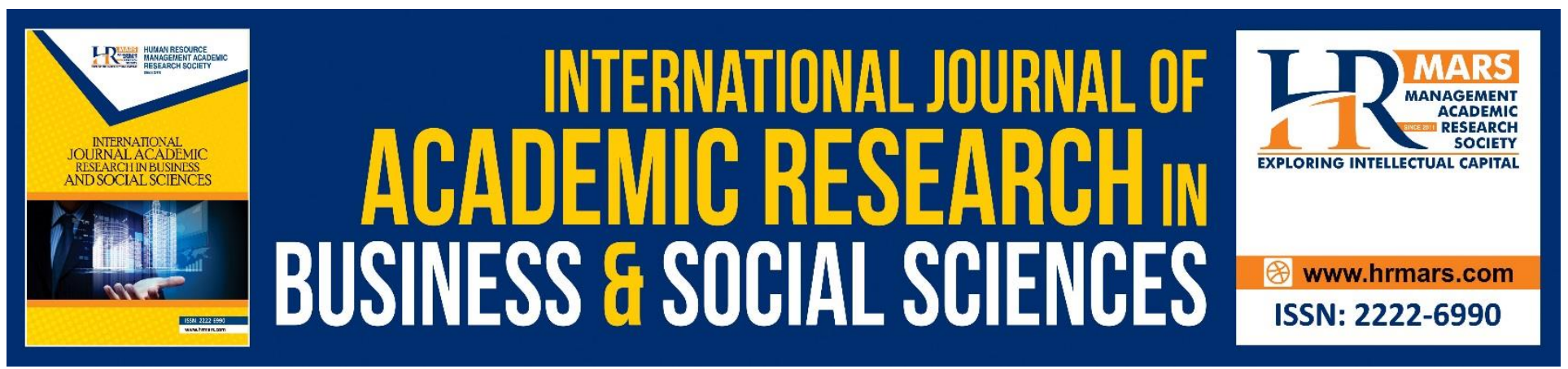

\title{
Effect of Environmental and Political/Legal Risk Management on Performance of Commercial Real Estate Entrepreneurial Investments in Kenya
}

\author{
James K Mbugua \\ University of Kabianga, Kenya \\ Email: jakambu01@gmail.com \\ Prof. Robert Otuya \\ University of Eldoret, Kenya \\ Email: robertotuya@yahoo.com \\ Dr. Stella Muhanji \\ Kabarak University, Kenya \\ Email:muhanjis@gmail.com
}

\begin{abstract}
The study adopted a descriptive survey design having a quantitative approach. The target population for this study was 9,320 real estate entrepreneurs comprised of 884, 95, 320 and 8,021 sourced from Softkenya directory, Kenya Developers Association, Estate Agent Registration Board and National Construction Authority respectively and having their registered offices in Nairobi, Nakuru, Kisumu and Eldoret. A sample size of 384 real estate entrepreneurs was selected and using a stratified random sampling procedure, them that participated in the study were identified and later served with online questionnaires using their emails. The primary data that was collected then analyzed descriptively and inferentially. Environmental risk management was found to a have a statistically significance effect on performance of commercial real estate entrepreneurial investments in Kenya. It further reveals that incomplete environmental analysis and unpredictable weather patterns were the two most frequent and severe sources of environmental risk. Political/legal risk management was however found not to have a statistically significant effect on the performance of the entrepreneurial investments. The study recommends the need by the concern authorities to enforce full compliance of environmental requirements before any entrepreneurial investment commences and throughout its life cycle and aided by real estate entrepreneurs and other stakeholders should further scrutinise all approvals that an entrepreneur requires with a view to determine the viability in the long run of the number of approvals as well as the number of
\end{abstract}


INTERNATIONAL JOURNAL OF ACADEMIC RESEARCH IN BUSINESS AND SOCIAL SCIENCES

Vol. 10, No. 5, May, 2020, E-ISSN: 2222-6990 @ 2020 HRMARS

institutions mandated to issue these approvals, ultimately aiming at establishing a one-stop shop in every County where all needed approval could be obtained.

Keywords: Risk Management, Entrepreneurship, Risk Factors, Performance, Commercial Real Estate Entrepreneurial Investments

\section{Introduction}

Entrepreneurs bear substantial risks and are said to be risk-takers for they commit significant resources to entrepreneurial investments whose outcome is somewhat uncertain. They are also known to undertake calculated risks by way of managing the risks in a bid to improving on the performance of their investment ventures (Koudstaal, Sloof, \& Praag, 2014). Amongst the many entrepreneurial investments is commercial real estate development.

Real estate sector is globally regarded as an integral part of a country's economy. It is responsible for a considerable part of its development investment with a sizeable amount of economic growth through backward and forward linkages to a considerable number of ancillary industries and sectors. Its contribution to GDP in 2010 was $28 \%$ (US) and $28 \%$ in the United Kingdom (Kongela, 2013). The GDP share of real estate in India was 6.3 per cent in 2013 and expected to generate 7.6 million jobs a year. In China, the GDP share of real estate grew from 5 per cent in 2000 to 15 per cent in 2012, with 14 per cent of urban employment coming from real estate and related sectors (Mutreja, Chua, \& Guha, 2015). Similar performance was realised by African states were real estate contribution to GDP was 6.82\% (Nigeria in 2014), 10.2\% (Tanzania, 2012) while in Kenya it registered 4.8\% of GDP in the year 2013 (Kongela, 2013; Kenya National Bureau of Statistics (KNBS), 2015).

Although this sector plays a pivotal role in economic development, the performance of real estate entrepreneurial investments has perennially been eclipsed by several challenges, including the management of its risks borne throughout their development life cycle. The resultant is a threat to its expected or intended performance (Wiegelmann, 2012). Risk, irrespective of its type, should be managed to achieve the desired outcome (Ghahramanzadeh, 2013). Given that projects undertaken in the real estate sector are widely complex and often have significant budgets, reducing associated risks should be a priority for each real estate entrepreneur (Gajewska, \& Ropel, 2011). Hence the need for the management of the risks. Although many investors enter real estate market because of its high growth potential and high profitability, achievability of properties' long term and short-term profitability objectives depend on how well the risks are managed (Koirala, 2012; Sibomanna, 2015). However, as observed by Gajewska and Ropel (2011), there are still many practitioners (entrepreneurs) that have not realised the importance of including risk management in the process of delivering their real estate investment projects. Additionally, Ghahramanzadeh (2013) found that reactive risk management is practised more than proactive risk management, resulting in dismal results.

\section{Global Perspective of Risk Management of Real Estate Entrepreneurial Investments}

Management of real estate entrepreneurial investments attract diverse perspectives globally. A study on the management of risk in Malaysia indicated that the Malaysian real estate industry is characterised by poor performance (Ayalew, Dekhili, \& Lafhaj, 2016). The study revealed that $92 \%$ of the construction of real estate investment projects could not be completed within the contract period, while $89 \%$ of the respondents stated that their projects were facing the problem of cost and 
INTERNATIONAL JOURNAL OF ACADEMIC RESEARCH IN BUSINESS AND SOCIAL SCIENCES

Vol. 10, No. 5, May, 2020, E-ISSN: 2222-6990 @ 2020 HRMARS

time overrun in the range of $5-10 \%$ of the contract. Similar findings were arrived at by Ghahramanzadeh (2013) in his study on Iranian real estate industry where reactive risk management is practiced more than proactive risk management, resulting to poor performance of the entrepreneurial investments. Akin challenges are recorded in the real estate sector in many African countries. Nketekete, Emuze and Smallwoods (2016) for instance postulate real estate entrepreneurial investments in Lesotho are failing due to prevalent risks. In some instances, failure has escalated in the region of $6 \%$ to $7 \%$ of contract costs, while in others a $90 \%$ failure rate has been recorded.

\section{Local Perspective of Risk Management of Real Estate Entrepreneurial Investments}

Real estate development is a complex and continually evolving business. In Kenya, the lucrative real estate sector has rapidly expanded to become the fourth biggest contributor to the country's wealth. In particular, the real estate sector has over the years, registered substantial growth in terms of its contribution to the GDP. In 2013, its contribution to sources of growth for GDP was standing at $4.8 \%$ up from $2.8 \%$ six years earlier. Real estate has, therefore, become a centre of focus for many investors, both local and foreign (Kibuyi, Ndiritu, Carcel, \& Gil-Alana, 2017).

Nonetheless, failure of real estate entrepreneurial investments in Kenya and the inadequacy of risk management actions within the sector is no different with respect to global reporting. In an audit report covering two and a half years of sampled counties by the National Buildings Inspectorate (NBI) some worrying findings were revealed; out of 4,879 buildings that were inspected during that period, 650 were categorised as very dangerous, 826 as unsafe, 1,185 fair while only 2,170 representing about 44\% were found to be safe for occupation (National Building Inspectorate, 2017). Kariungi (2014) and Githenya and Ngugi (2014) postulate that although risks are managed every day in the Kenyan real estate industry, they are not managed in a structured way and knowledge of risk management was close to zero resulting in them not always meeting key performance goals. Failure of any commercial real estate entrepreneurial investment in terms of construction time overrun, budget overrun, poor quality (resulting in the collapse of buildings or costly maintenance), delayed or non-occupation after completion, and demolition (due to illegal or inadequate land acquisition procedures on allegedly public land or road reserves), results in heavy financial losses and/or expensive and protracted court cases on the side of real estate entrepreneur.

\section{Statement of the Problem}

Notwithstanding the fact that the Kenya government, its development partners as well as commercial real estate entrepreneurs have continued to allocate huge financial resources to finance real estate developments in a bid to earn from these investments, more than $70 \%$ of real estate entrepreneurial investments in Kenya experience time overrun of the magnitude of over $50 \%$, while $50 \%$ of the real estate investments experience excess cost budget of a magnitude of more than 20\% (Auma, 2014; Gwaya, Masu, \& Wanyona, 2014). In the year 2015, office space absorption levels dipped, rental levels for retail outlets stagnated while the residential accommodation uptake was low (KnightFrank, 2015). In regard to structural failure, collapsing of buildings have reached an 'alarming stage' in the past few years with several buildings structurally failing (Kioko, 2014; Fernandez, 2014). To date, a total of 87 cases of buildings that have collapsed and a death toll of 170 people has been recorded (Kabala, 2019). On financial performance, the commercial real estate entrepreneurial investments 
have been declining in the recent times with defaults on mortgage standing at 38 billion shillings by December 2018 and property forfeiture by the financial institutions being on the increase (Central Bank of Kenya, 2018).

Much of such failure have been attributed to the lack of proper risk management, lack of adequate insight on key risk factors and their criticality and failure to manage real estate entrepreneurial investment risks in a systematic way by the entrepreneurs (Wan, Daud, Zainol, \& Mumin, 2017). . In this case, therefore, for the performance of commercial real estate entrepreneurial investments to be realised, insight on key risk factors, their effects on performance and how they are dealt with is necessary to the entrepreneurs. Extant studies in Kenya regarding the failure of commercial real estate entrepreneurial investments have evidently missed out on attribution of such failure to risk management of commercial real estate entrepreneurial investments.

\section{Purpose of the Study}

The purpose of this study is to determine the effect of environmental and political/legal risk management on performance of commercial real estate entrepreneurial investments in Kenya.

\section{Objectives of the Study}

i) To assess the effect of environmental risk management on the performance of commercial real estate entrepreneurial investments

ii) To examine the effect of political risk management on the performance of commercial real estate entrepreneurial investments

\section{Research Hypotheses}

i) $\quad H_{0} 1$ : Management of environmental risk does not have a statistically significant effect on the performance of commercial real estate entrepreneurial investments

ii) $\quad H_{0}$ 2: Management of political risks does not have a statistically significant effect on the performance of commercial real estate entrepreneurial investments

\section{Literature Review}

\section{Entrepreneurship, Risk and Risk Management}

Entrepreneurship is the willingness and ability of an individual to seek out investment opportunities and take advantage of scarce resources to exploit the opportunities profitably. It is the process of creating something new with value by devoting the necessary time and efforts, assuming the accompanying financial, psychic and social risks, and receiving at the end receiving resulting rewards of monetary and personal satisfaction and independence (Mbazor, Adedayo, \& Ige 2017; Hisrich, \& Peters, 2002). Entrepreneurship in real estate as opined by Wiegelmann, (2012) entails combining resources such as land, labour and capital to plan, develop, manage and market facilities which provide services (accommodation) demanded by space users. To minimise losses and increase profits, these resources, along with its associated risk, should be recognised and managed. Akin to other business ventures, a hereditary risk exists in all the processes of real estate entrepreneurial investment starting from the ideation, conceptualisation, property production, commercialisation and ending with the disposal or management of the investment. 
The word 'risk' is a common and widely-used part of today's vocabulary, yet somewhat surprisingly, there is still no broad consensus on the meaning of this term (Wiegelmann, 2012; Gehner, 2008). However, in order to make the concept of risk operational, risk is usually defined as a function of probability and impact. The probability of a risk event represents the chance or likelihood that an event will occur. The impact or consequence of a risky event is expressed in terms of deviation from the expected or desired outcome (Gehner, 2008). There are many and varied views and descriptions of what risk management involves, how it should be conducted and what it is for Wiegelmann, (2012), leading to various definitions and number of stages in the process. According to Wiegelmann (2012), risk management is a structured and disciplined approach that aligns strategy, processes, people, technology and knowledge with the purpose of evaluating and managing the uncertainties a real estate organisation faces as it creates value. Nielsen (2010) introduces a further aspect of risk management to mean the identification, assessment, and prioritisation of risks followed by coordinated and economical application of resources to minimise, monitor, and control the probability and/or impact of unfortunate events or to maximise the realisation of opportunities.

Alongside the discussion on entrepreneurship, risk definition, risk management and risk management process, scholars have also equally spent some time in discussing its classification. Risk classification relates to how an organisation defines the risks it faces. Although it is impossible to list all the risks in a real estate entrepreneurial investment, risks are usually categorized into clusters so as to have a wider spectrum and inclusiveness which in return will help manage risks effectively. They are validly categorized in literature (Gajewska, \& Ropel, 2011; Koirala, 2012) including categorization advocated by Boateng, Chen, Ogunlana and Kediashi et al., (2012) comprising of Technical risk, Financial/economic risk, market risk, environmental risk, political/legal risk and property operational risks. This study is however concerned with environmental and political/legal risks.

\section{Environmental Risk Management and Performance of Real Estate Entrepreneurial Investment}

Effects of environment on a real estate entrepreneurial investment are associated with risks on natural hazards and influences of nature on the project. Similarly, in practice, environmental risk will include considerations such as the possible contamination, pollution and emissions on the site (such as different harmful chemicals and radiation) that might cause significant purifying liabilities for the entrepreneur during construction or post-construction phases (Kohonen, 2015) and non-adherence to environmental laws and requirements. Many only see weather disruptions as the direct time lost during the bad weather. Unfortunately, some events can cause damage to partly completed structures which could take days or weeks to repair.

Several environmental attributes that would affect the performance of the investment have been indicated in the literature to include climate change, severe weather condition such as wind, precipitation, floods and hail. Newell and Steglick (2006) in their study on assessing property development risk factors in Australia, they found that environmental risk was the highest risk factor not only in the pre-construction phase but was regarded as the overall highest risk impacting on performance. However, Wang, Dulaimi and Aguria (2004) in an evaluation performance of real estate properties in developing countries, the environmental risk was found to have the least impact on their success. 
INTERNATIONAL JOURNAL OF ACADEMIC RESEARCH IN BUSINESS AND SOCIAL SCIENCES Vol. 10, No. 5, May, 2020, E-ISSN: 2222-6990 @ 2020 HRMARS

\section{Political/legal Risk Management and Performance of Real Estate Entrepreneurial Investment}

Political/Legal risk is risks that may arise from the interactions between the government and the surrounding environment or society. Typically, they prevail from politically motivated events that adversely affect investments, contracts, or other businesses, be it national or international. For instance, in an unstable political condition, people are unable to make correct predictions on future economic development. Similarly, in a situation of frequent change in government, the policy made by one government may be changed by the incoming government. These situations end up hiking the uncertainty within the industry (Koirala, 2012). Other sources of political risk include a change in law, corruption and delays in approval (Wang et al., 2004). Corruption is defined as the misuse of power for private gain either at one's own instigation or in response to inducements and it undermines the delivery of services (Sohail, \& Cavill, 2008). Real estate entrepreneurial developments operate with a legal framework of planning and environment regulations, codes of practice, safety regulation, insurance, conveyancing and taxation laws (Akanni, Oke, \& Akpomiemie, 2015). These laws, code and regulations are generally well defined, making it relatively possible to predict their impact on real estate entrepreneurial investments. However, any changes that might occur during the life cycle of the entrepreneurial investment or non-adherence bring about a risk challenge. Muka, Tewin, \& Wibowo (2015) and Jaber (2014) found that political risk was rated to have the highest risk level in real estate investments in Indonesia and Iran respectively.

Time, cost and quality are the three predominant performance criteria used in real estate entrepreneurial investments, traditionally referred to as the "iron triangle". A general assumption is at times made that if a project is completed on time, within the agreed budget and set quality (the iron triangle) the project is deemed successful. However, evidence suggests that this is not always the case since there are projects that meet all the three targets, yet considered failure. For instance a property that although meets all the criteria, and yet has a very low commercial success may not necessary be considered a success. Subsequently to capture performance of commercial real estate properties throughout their development lifecycle; during construction and post construction, this study adopted four performance criteria namely: time, cost, return on investment and client's satisfaction.

\section{Theoretical Framework}

The study was guided by two theoretical approaches namely: Strategic planning theory and Contingency theory

\section{Strategic Planning Theory}

The theory, domicile in the strategic formulation school of thought of entrepreneurship, emphasises the planning process in successful venture development (Fredrick, O'Connor, \& Kuratko, 2016). The use of strategy in decision-making is the primary way in which real estate entrepreneurs take into account of a constantly changing external environment. An effective strategy allows them to use their organisation's resources and capabilities to exploit opportunities and limit threats in the external environment in order to achieve competitive advantage (Quaye et al., 2015). Risk management is about making decisions from a set of options on how best to minimise the impact of the threats to the firm's objectives. With the real estate entrepreneurs faced with a myriad of risks threatening the performance of their entrepreneurial investments, strategic planning is crucial. The best strategic plan will be influenced by many factors, among them the ability of the entrepreneur, the complexity 
of the venture and the nature of the industry (Kuratko, \& Hodgetts, 2000). The further postulate that irrespective of the situation, strategic planning follows five basic steps namely; to examine the internal and external environment of the venture, formulate the venture's long-range and shortrange strategies, to implement the strategic plan, to evaluate the performance of the strategy and to take follow up action through continuous feedback. Real estate entrepreneurial investments are complex and multidisciplinary, and therefore, management of its risks will require a systematic approach advocated by the strategic formulation school of thought.

\section{Contingency Theory}

This is a management theory adapted in various management concepts in literature. It originated with the work of Woodward (1958) as a response to rapid changes and increasing environmental uncertainty. The theory proposes that there are many ways to attain a given end but for every situation there is an ideal way to attain that end, in order to achieve optimal organizational performance (Mitchell, 2006), and that the optimal course of action is contingent (dependent) upon the internal and external situation (Hai \& Nawi, 2012). In this case, an organization should strive to establish relationship with the environment and through decision making manipulate the relationship to attain optimal organizational performance. The theory is based on the premise that to every situation there is an optimal fit. The closer to the fit the higher the performance. The relevance of this theory to the current study is that management of risks in real estate is contingent to the type and nature of risks. There is no one best fit strategy for managing all risks but with every risk category there should be a different management strategy. In adopting contingency theory, this study hypothesizes that the closer the fit between the real estate entrepreneur's way of managing the risks and systematic risk management procedure, the greater is the performance of the respective commercial real estate entrepreneurial investment.

\section{Research Methodology}

The study adopted a descriptive survey design having a quantitative approach. The target population for this study was 9,320 real estate entrepreneurs comprised of 884, 95, 320 and 8,021 sourced from SoftKenya directory (SoftKenya, 2018), Kenya Developers Association (KPDA, 2018), Estate Agent Registration Board (estateagentsboard.or.ke) and National Construction Authority (GOK, 2016) respectively and having their registered offices in Nairobi, Nakuru, Kisumu and Eldoret. A sample size of 384 participants was selected and using a stratified random sampling procedure, participants that participated in the study were identified and later served with online questionnaires using their emails. Reliability of the questionnaires was tested for internal consistency using the Cronbach's coefficient alpha. The alpha coefficients for the items in the questionnaires were above 0.7 indicating acceptable reliability. The collected data was analysed descriptively and inferentially using frequency distribution - mean and standard deviation, Chi-square, Pearson's Correlation and multiple linear regression analysis with the aid of the Statistical Package for Social Sciences (SPSS), version 20.0. The significance of each risk factor within the categories was examined using Risk Significant Index formula advocated by (Gupta et al. 2016; Darwish, \& Abdeldayem, 2019). 
INTERNATIONAL JOURNAL OF ACADEMIC RESEARCH IN BUSINESS AND SOCIAL SCIENCES

Vol. 10, No. 5, May, 2020, E-ISSN: 2222-6990 @ 2020 HRMARS

\section{Findings and Discussion \\ Demographic Findings}

To examine the relationship between risk management and performance of commercial real estate entrepreneurial investments in Kenya, descriptive and inferential analysis was employed. Three hundred and twenty-four (324) questionnaires were received back representing $84 \%$ response rate. Majority of respondents were mainly aged between 31 and 40 years, accounting for $42.3 \%$ of the respondents. Slightly more than a quarter of the respondents were aged below 30 years, an indication that the sector is attracting the younger professionals. Regarding respondent's highest levels of education, close to a half (47.8\%) of the respondents had an undergraduate degree as their highest level of education. Diploma holders who accounted for $31.5 \%$ of the responses followed while those with postgraduate qualification accounted for $20.7 \%$ of the responses. A look at the respondent's profession reveals that contractors were the most dominant making up $37 \%$ of the total responses followed by project managers and valuers and estate agents who accounted for $24.1 \%$ and $19.4 \%$ of the responses received respectively. A significant proportion of the respondents hold less than 10 years' experience in the sector with the majority (41\%) having been in the sector for between 5 and 10 years while those with more than 15 years accounted for $23.1 \%$ of the respondents. On management of risks, the study found that over $60 \%$ of the respondents have low knowledge on risk management procedure leading to $71.3 \%$ of the real estate entrepreneurs relaying on informal risk management approaches such as judgement, intuition and experience.

Numerous types of risk exposure directly or indirectly affect the performance of commercial real estate entrepreneurial investments. In the current study, two types of risk categories were identified for analysis; environmental risk and political/legal risk. It is important to note that the risk category are not independent of each other but have a collective contribution to the overall risk levels in a real estate investment. Ranking of Risk category based on perceived assessment is shown in table 1.

Table 1: Ranking of Risk category based on perceived assessment

\begin{tabular}{|c|c|c|c|c|c|c|c|c|c|c|}
\hline Risk Type & LC & SC & MDC & C & VC & MSC & $\begin{array}{l}\text { \%Me } \\
\text { an }\end{array}$ & Chi Sq & $\begin{array}{l}\text { P- } \\
\text { valu } \\
\text { e }\end{array}$ & $\begin{array}{l}\text { Ran } \\
k\end{array}$ \\
\hline $\begin{array}{l}\text { Environm } \\
\text { ental }\end{array}$ & $\begin{array}{l}35 \\
(10.8 \% \\
)\end{array}$ & $\begin{array}{l}43 \\
(13.3 \% \\
)\end{array}$ & $\begin{array}{l}64 \\
(19.8 \% \\
)\end{array}$ & $\begin{array}{l}79 \\
(24.4 \% \\
)\end{array}$ & $\begin{array}{l}71 \\
(21.9 \% \\
)\end{array}$ & $\begin{array}{l}32 \\
(9.9 \%)\end{array}$ & $\begin{array}{l}60 . \\
5\end{array}$ & 36.7 & $\begin{array}{l}.00 \\
0\end{array}$ & 1 \\
\hline $\begin{array}{l}\text { Political/ } \\
\text { legal }\end{array}$ & $\begin{array}{l}124 \\
(38.3 \% \\
)\end{array}$ & $\begin{array}{l}45 \\
(13.9 \% \\
)\end{array}$ & $\begin{array}{l}83 \\
(25.6 \% \\
)\end{array}$ & $\begin{array}{l}23 \\
(7.1 \%)\end{array}$ & $\begin{array}{l}38 \\
(11.7 \% \\
)\end{array}$ & $\begin{array}{l}11 \\
(3.4 \%)\end{array}$ & $\begin{array}{l}41 . \\
7\end{array}$ & $\begin{array}{l}164 . \\
6\end{array}$ & $\begin{array}{l}.00 \\
0\end{array}$ & 2 \\
\hline
\end{tabular}

LD; Least critical, SC; Somewhat Critical, MDC: Moderately Critical, C: Critical, VC: Very Critical, MSC: Most Critical. Chi sq $=* * *$

Environmental risk was perceived to be more crucial than the political/legal risk amongst the respondents having a mean score of $60.5 \%$ as compared to $41.7 \%$ respectively. This could be attributed to the growing awareness of its importance caused by massive demolitions of real estate entrepreneurial developments in the recent times allegedly due to lack of due diligence in conveyancing, violation of environmental legislations and active enforcement of environmental laws by the relevant authorities. To achieve a deeper understanding of the nature of risks inherent in real 
INTERNATIONAL JOURNAL OF ACADEMIC RESEARCH IN BUSINESS AND SOCIAL SCIENCES

Vol. 10, No. 5, May, 2020, E-ISSN: 2222-6990 ㄷ 2020 HRMARS

estate entrepreneurial investments, risk factors based on their prevalence/frequency and severity as constituted in each risk category was sought by computing the risk index score of each risk factor. The results showing risk index score for the environmental risk is summarized in Table 2.

Table 2: Risk Index score of environmental risk

\begin{tabular}{llll}
\hline Environmental risk factors (indicators) & Mean & SD & Rank \\
\hline Unpredictable weather condition on completion of project & 0.554 & 0.230 & 2 \\
Incomplete environmental Analysis & 0.613 & 0.295 & 1 \\
Acts of God & 0.254 & 0.179 & 3 \\
\hline
\end{tabular}

Failure to complete environmental analysis as a potential source of the environmental risk exposure was the most prevalent factor attaining a risk index factor of $M=0.613, S D=0.295$, as shown in Table 2. Environmental occurrences that are beyond the control of players in the real-estate sectors; acts attributed to God, are rare in Kenya as confirmed by lower rating. Broadly, weather conditions in Kenya are predictable and seasonal. It would be expected, therefore that, at the planning phase, adequate measure be put in place to mitigate any potential adverse effects.

Table 3: Risk Index score of political/legal risk

\begin{tabular}{llll}
\hline Political Risk factors (indictors) & Mean & SD & Rank \\
\hline Corruption or bribery & 0.738 & 0.293 & 1 \\
Changes in zoning laws and other government rules, & 0.42 & 0.21 & 3 \\
controls and regulations & 0.67 & 0.303 & 2 \\
Delay in dispute Resolution & 0.394 & 0.192 & 4 \\
Political/civil disturbance & & \\
\hline
\end{tabular}

Corruption or bribery $(M=0.738, S D=0.293)$ and delay in dispute resolution $(M=0.670, S D=0.303)$ were ranked the riskiest political/legal risk factors in that order. Political/civil disturbance $(M=0.394$, $\mathrm{SD}=0.192$ ) attained the least position after changes in physical planning and other government laws, controls and regulations $(M=0.420, S D=0.210)$. Kenya continues to perform dismally in the global corruption perception index consistently attaining a score of less than 30 out of the possible 100 (Transparency International, Kenya, 2019). The real estate sector has not escaped from the vise, making it not only the most prevalent but also the most severe in terms of its consequences. High prevalence of corrupt practices is linked to bureaucratic procedures and lack of adequate real estate entrepreneurial investment information that leads to unfavourable outcomes.

\section{Inferential Findings}

The overall objective of this study was to determine the effect of environmental and political/legal risk management on the performance of commercial real estate entrepreneurial investments in Kenya. To arrive at a definitive conclusion on the effect of individual risk category, two hypotheses were considered for analysis. Regression analysis is shown in table 4. 
INTERNATIONAL JOURNAL OF ACADEMIC RESEARCH IN BUSINESS AND SOCIAL SCIENCES Vol. 10, No. 5, May, 2020, E-ISSN: 2222-6990 @ 2020 HRMARS

Table 4: Multiple Regression Results

\begin{tabular}{llllll}
\hline Model & \multicolumn{2}{l}{ Unstandardized Coefficients } & $\begin{array}{l}\text { Standardised } \\
\text { Coefficients } \\
\text { Beta }\end{array}$ & $\mathbf{t}$ & Sig. \\
\hline (Constant) & 1.626 & .164 & & 9.904 & $.000^{*}$ \\
PRMGT & .045 & .059 & .051 & .759 & .448 \\
ERMGT & .142 & .047 & .183 & 3.041 & $.003^{*}$ \\
\hline
\end{tabular}

a. Dependent Variable: PERFORMANCE

b. Predictors: (Constant), ERMGT,PRMGT, Significance *

The estimated environmental risk management coefficient of 0.142 indicates that a unit increase in environmental risk management score led to a $14.2 \%$ improvement in the performance of real estate entrepreneurial investments. With the test coefficient $p$-value of less than 0.05 , the null hypothesis was rejected, leading to a conclusion that management of environmental risk significantly affects the performance of real estate entrepreneurial investments in Kenya. In Kenya where extreme weather conditions are rare, incidences of serious environmental hazards are relatively unheard of, adherence to environmental requirements prior, during and after construction, can be the main justification. This will imply that environmentally friendly and compliant real estate entrepreneurial investments would attract better prices and occupancy and hence improved performance. Political/legal risk management has a positive coefficient of 0.045 indicating that a unit increase in political/legal risk management score led to $4.5 \%$ increase in performance of commercial real estate properties in Kenya. However, the resulting t-test $\mathrm{p}$-value was greater than 0.05 ; consequently, the null hypothesis failed to be rejected. This led the study to conclude that management of political/legal risk does not affect the performance of real estate entrepreneurial investments in Kenya. The political environment in Kenya has remained relatively stable and investor-friendly. The relative stability experienced in the political/legal fronts justified the minimal influence of political/legal risk management on the performance of real estate entrepreneurial investments in Kenya

\section{Summary, Conclusions and Recommendations Summary and Conclusion}

Incomplete environmental analysis and unpredictable weather patterns were the two most frequent and severe sources of environmental risk in commercial real estate sector in Kenya with a Risk Index Significance of 0.613 and 0.554 respectively (Table 2). On managing the environmental risks, the entrepreneurs' compliance with Environmental impact assessment requirements, exclusion of extreme weather conditions during bidding and contract pricing and scheduling phases of real estate entrepreneurial investment in line with favourable weather conditions are the most widely used environmental risk management strategies.

Risk factors in the political/legal risk category were divided into two sets; politically generated and legal or regulatory generated. The corruption or bribery-related risks and delays in dispute resolution were identified as the two main sources of political/legal risk having a Risk Index Significance of 0.738 and 0.670 , respectively. Corruption/bribery risk not only undermines the delivery of services but also leads to poor quality construction in terms of substandard use of building materials, poor workmanship and misappropriation of funds. Several factors are cited to be responsible for litigations in the real estate sector; the undefined scope of work, lack of 
familiarity with other team members, insufficient funding and firms prone to litigious behaviour. There is a general agreement that the best approach to litigation is to avoid it whenever possible. Political risk insurance that would take care of damage or losses brought about by political disturbances and other related cases as well as establishing a dispute resolution procedure were the most preferred management approaches by the respondents

For the entrepreneur to manage effectively risks of his/her real estate entrepreneurial investment and enhance its performance, a clear understanding of the nature and criticality of the risk factors is paramount and especially given the limited resources available to manage these risks. The awareness shared in this study of managing these risks and their prioritization will be of great help to the entrepreneur in his/her risk response strategy. Secondly, besides filling the knowledge gap especially in developing countries on the effects of risk management on the performance of commercial real estate entrepreneurial investments by investigating the effects of environmental and political/legal risk management, the study will be of great help to the financiers when undertaking the mortgagor's analysis as an audit tool in assessing the entrepreneur's awareness of the potential risk factors and their management. This will help minimize default risk where the entrepreneur is unable to meet the mortgage repayments.

\section{Recommendation}

The study reveals that incomplete or poor environmental analysis are critical in the performance of commercial real estate entrepreneurial investments. There is need, therefore, for the concern authorities to first, help create awareness of these risks amongst the real estate entrepreneurs and secondly make sure there is full compliance of environmental requirements by the entrepreneurs before any entrepreneurial investment commences and throughout its life cycle. Although political/legal risk management was found not to statistically significance affect performance, the risk was found to be crucial.

In this regard, the government-aided by real estate entrepreneurs should further scrutinise all approvals that an entrepreneur require with a view to determine the viability in the long run of the number of approvals as well as the number of institutions mandated to issue these approvals. There is need also to find the possibility of establishing a one-stop shop in every County to reduce bureaucracy.

\section{References}

Akanni, P. O., Oke, A. E., \& Akpomiemie, O. A. (2015). Impact of environmental factors on building project performance in Delta state, Nigeria. Housing and Building National Research Centre (HBRC) Journal, 11, $91-97$.

Auma, E. (2014). Factors affecting the performance of construction projects in Kenya: A survey of low-rise buildings in Nairobi Central Business district. International Journal of Business and Management, 2(10), 115-140.

Ayalew, T., Dakhili, Z., \& Lafhaj, Z. (2016). Assessment of performance and challenges of the Ethiopian construction industry. Journal of Architecture and Civil Engineering, 2 (II).

Boateng, P., Chen, Z., \& Ogunlana, S. O. (2015). An analytical Network process model for risk prioritization in mega projects. International Journal of Project Management, 33 (8), 17951811. 
INTERNATIONAL JOURNAL OF ACADEMIC RESEARCH IN BUSINESS AND SOCIAL SCIENCES

Vol. 10, No. 5, May, 2020, E-ISSN: 2222-6990 @ 2020 HRMARS

Central Bank of Kenya. (2018). Bank supervision annual report 2018. Retrieved December 20, 2019, from https://www.centralbank.go.ke > uploads > 1174296311_2018 Annual Report.

Darwish, S., \& Abdeldayem, M. M. (2019). Risk Management and Business Ethics: Relations and Impacts in the GCC. International Journal of Civil Engineering and Technology, 10(10), 489504.

Fernandez, R. H. F. (2014). Strategies to reduce the risk of building collapse in developing countries. Thesis and Dissertations at Research showcase CMU Dissertation paper 493. Retrieved December 23, 2017, from http://repository.CMU.edu/dissertations

Fredrick, H., O'Connor, A., \& Kuratko, D. F. (2016). Entrepreneurship: Theory, process and practice $\left(4^{\text {th }}\right.$ Ed.). South Melbourne. Cengage Learning Australia Pty Ltd.

Gajewska, E., \& Ropel, M. (2011). Risk management practices in a construction project: A case study. M.Sc. Thesis. Chalmers University of Technology, Goteborg Sweden. Retrieved November 27, 2017, from https://www.researchgate.net/file.PostFileLoader.html?id...asset Key...

Gehner, E. (2008). Knowingly taking risks: Investment decision making in real estate. The Netherlands: Eburon Academic Publishers. Retrieved November 13, 2017, from repository.tudelft.nl/assets/uuid:4ad6a43e-1655-428e-b983.../gehner_20081202.pdf

Ghahramanzadeh, M. (2013). Managing risk of construction project: A case study of Iran. Unpublished PhD Thesis. University of East London. Retrieved March 27, 2017, roar.uel.ac.uk/3502/1/2013_PhD_Ghahramanzadeh.pdf

Githenya, M. S., \& Ngugi, K. (2014). Assessment of the determinants of implementation of housing projects in Kenya. European Journal of Business Management, 1(II).

GOK. (2016). The national Construction Authority Act. The Kenya Gazette, CXVIII (41). Nairobi. Government Printers.

Gupta, D., Sharma, M., \& Trivedi, A. S. (2016). Risk Management Identifying key risks in construction projects. International Journal of Civil and Structural Engineering Research, 4(1), 9-15.

Gwaya, A. O., Masu, S. M., \& Wanyona, G. (2014). A critical analysis of the cause of project management failures in Kenya. International Journal of Soft Computing and Engineering, 4(1), 64-69.

Hai @lbrahim, J. C., and Nawi, N. F. (2012). Principles of Public Administration: Malaysian Perspectives. Kuala Lumpur: Pearson Publishers.

Hisrich, R. D., \& Peters, M. P. (2002). Entrepreneurship. New York. McGraw-Hill/Irwin.

Jaber, F. K. (2014). Establishing risk management factors for construction projects in Iraq. International Journal of Advanced Research in Engineering and Technology (IJARET), 6(1) 3548.

Kabala, W. (2019). Building failures. National Construction Authority (NCA) Quarterly Report March 2019, 16 - 20. Retrieved December 20, 2019, from https://nca.go.ke > wp-content > uploads > 2019/08 > quarterly-march-2019.

Kariungi, S. (2014). Determinants of timely completion of projects in Kenya: A case of Kenya Power and Lighting Company, Thika. ABC Journal of Advanced Research, 13 (2), 9-20.

Kenya National Bureau of Statistics (KNBS). (2015). Economic Survey, 2015. Nairobi. Government Printers.

Kibuyi, D., Ndiritu, S. W., Carcel, H., \& Gil-Alana, L. (2017). Real estate prices in Kenya: Is there a bubble? Journal of Housing and Built Environment, 1-18. 
INTERNATIONAL JOURNAL OF ACADEMIC RESEARCH IN BUSINESS AND SOCIAL SCIENCES

Vol. 10, No. 5, May, 2020, E-ISSN: 2222-6990 @ 2020 HRMARS

Kioko, J. M. (2014). Causes of building failures in Africa. A case on collapsing structures in Kenya. IOSR Journal of mechanical and Civil Engineering (10SR-jmce), II (3), 09-10.

KnightFrank. (2015). Knightfrank Research. Retrieved December 20th 2017 from KnightFrank.com/Research. www.KnightFrank.co.ke/resources/kenyamarket-update.

Kohonen, A. (2015). Management of unsystematic risks in commercial real estate asset management. Unpublished M.Sc. Thesis Aalto University. Retrieved July 23, 2017, from htts://aaltodon.fi/bit stream/handle/.../masters - Kohonen Aleksi-2015 pdf

Koirala, M. P. (2012). Risk in housing and real estate construction projects: Study in Nepal. Unpublished PhD Thesis. Singhania University. Retrieved July 23, 2017, from www.nepjol.info/index.php/JIE/article/download/10876/8859

Kongela, S. M. (2013). Framework and Value Drivers for Real Estate Development in Sub - Saharan Africa: Assessment of the Tanzanian Real Estate Sector in the context of the Competitiveness model. Dissertation. University of Regensburg. Retrieved November 23, 2017, from https://epub.uni-regensburg.de/29551/6/65.pdf

Koudstaal, M., Sloof, R., \& Praag, M. (2014), Risk, uncertainty and entrepreneurship: Evidence from a lab-in-the-field Experiment, No 8577, IZA Discussion Papers, Institute of Labour Economics (IZA).

KPDA. (2018). KPDA Directory of Members. 2018, February. Retrieved June 4, 2018, from www.kpda.or.ke

Kuratko, D. F., \& Hodgetts, R. M. (2000). Entrepreneurship. A contemporary approach (5 ${ }^{\text {th }}$ Ed.). Philadelphia: The Harcourt College Publishers.

Mbazor, D. N., Adebayo, M. A., \& Ige, V. O. (2017). Relevance of entrepreneurship education in real estate practice for sustainable national growth. European Journal of Educational Sciences (EJES), 4(2), $121-135$.

Mitchell, E. B. (2006) Applying and assessing a contingency model for online learning policy implementation in higher education. Unpublished PhD thesis, Simon Fraser University Canada. Retrieved March 4, 2018, from summit.sfu.ca/system/files/iritems1/2460/etd2264.pdf.

Muka, W., Tamin, R. Z., \& Wibowo, A. (2015). Property development risk. A case study in Indonesia. International Referred Journal of Engineering and Science (IRJES, 4(7), 21-26.

Mutreja, R., Chua, M., \& Guha, A. (2015). The role of corporate real estate in developing countries of the Asia-Pacific region. Corporate Real Estate Journal, 4(4), 314-322.

National Building Inspectorate. (2017). General report on the state of affairs on the National buildings Inspectorate. Retrieved February 10, 2018, from http://nca.go.ke/new/src/research/research-publications/

Newell, G., \& Steglick, M. (2006). Assessing the importance of property development risk factors. Pacific Rim Property Research Journal, 12(1), 22-37.

Nielsen, D. B. (2010). Risk Management reporting and value creation in Danish companies. Retrieved December 19, 2017, from Studentthesis.ebs.dk/bitstream/handle/10417/1164/dennis-boetern-nielsen.pdf

Nketekete, M., Emuze, F., \& Smallwoods, J. (2016). Risk management in public sector construction projects: Case studies in Lesotho. Actastructilia, 23(2), 1-24.

Quaye, I., Osei, A., Sarbah, A., \& Abrokwah, E. (2015). The applicability of the learning school model of strategy formulation (Strategy Formulation as an Emergent Process). Open Journal of Business and Management, 3, 135-154. 
INTERNATIONAL JOURNAL OF ACADEMIC RESEARCH IN BUSINESS AND SOCIAL SCIENCES

Vol. 10, No. 5, May, 2020, E-ISSN: 2222-6990 @ 2020 HRMARS

Sibomana, A. (2015). Effects of risk management methods on project performance in Rwandan construction industry. A case of multi-storey buildings construction project of (RSSB). Master Thesis. Jomo Kenyatta University of Agriculture and Technology, Kigali Campus. Retrieved March, 2018, from www.jkuat.ac.ke/.../Aimable.

SoftKenya. (2018). Kenya Directory of Property Developers. Retrieved February 12, 2018, from https://softkenya.com/directory/real-estate-developers-in-kenya/

Sohail, M., \& Cavill, S. (2008). Accountability to prevent corruption in construction projects. Journal of Construction Engineering and Management, 134(9), 729-738.

Wan, D. W., Zainol, F. A., \& Mumin, M. H. (2017). What causes abandoned residential housing projects in Malaysia? An insight from economic and management perspectives. International Journal of Academic Research in Progressive Education and Development, 6(4), 57-73.

Wang, S., Dulaimi, M., \& Aguria, Y. (2004). Risk management framework for construction projects in developing countries. Construction Management and Economics, 22(3), 237-252.

Wiegelmann, T. W. (2012). Risk management in real estate development industry. Unpublished PhD Thesis. Bond University. Australia. Retrieved September 3, 2017, from epublications.bond.edu.au/cgi/viewcontent.cgi?article=1116\&context=theses

Woodward, J. (1980). Industrial organization: Theory and practice (2 ${ }^{\text {nd }}$ Ed.). Oxford: Oxford University Press. 